\title{
3 Structural changes in the Polish and Ukrainian economies against the background of other Central and Eastern European countries
}

\author{
Rafat Wisła, Svitlana Chugaievska, \\ Andrzej Nowosad and Umit Turanli
}

\subsection{Introduction}

In June 1989, communism ended in Poland. The inflation rate was $640 \%$ per annum, the Polish currency did not have a widely accepted internal exchangeability - the market converted it to dollars - and shop shelves were bare. Poland was threatened with an economic catastrophe. The free market, fight against inflation, budgetary discipline, politically independent monetary policy, opening up to foreign trade and sanctioning unemployment were the main assumptions and tools of Poland's new economic policy. In the early 1990s, the Polish economy underwent a revolution.

In 1989, Ukraine was one of the republics of the Union of Soviet Socialist Republics (USSR) whose independent economy was part of an inefficient Soviet economic organism. As a result of the 1990s systemic transformation in Ukraine was overtaken by conglomerates, while output in all production sectors decreased by more than $50 \%$. Hyperinflation in the early 1990 s was the result of, amongst others, a lack of independence of the Central Bank of Ukraine, which led to a destabilization of the state's finances and a significant devaluation of the Ukrainian currency.

In Ukraine the 1990s were a period of deep economic recession. The situation in Ukraine was also indirectly exacerbated by the Russian financial crisis of 1998, which did not have much impact on Poland. The Ukrainian GDP per capita (in PPPs, at fixed prices from 2011) fell from 9,500 USD in 1991 to 4,500 USD in 1999. In 2017, it did not retain its 1991 level-7,900 USD per capita. By comparison, in Poland, the GDP per capita has grown by nearly $190 \%$ over the last 27 years from 9,500 USD in 1991 to 27,000 USD in 2017 (Figure 3.1). In 2018, the Polish GDP per capita was three times higher than in 1991 (The World Bank 2019).

Between 2000 and 2007, the real GDP per capita increased by $83 \%$ in Ukraine. The Russian financial crisis combined with the gas conflict with Russia led to a one-year, significant recession in Ukraine in 2009 (nearly 


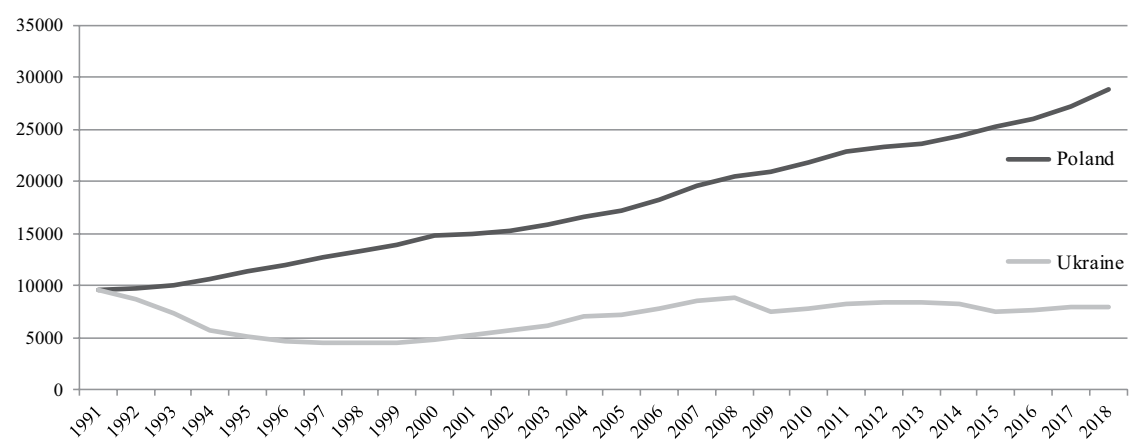

Figure 3.1 GDP per capita in Poland and Ukraine between 1990 and 2018 (USD, PPPs, in 2011 prices).

Source: The World Bank Group, Indicators, (2019). (https://data.worldbank.org/indicator/ NY.GDP.PCAP.PP.KD?locations=UA-PL\&view=chart, access: 2019-12-30).

a $15 \%$ decrease), after which, in 2010 , the Ukrainian economy returned to the path of economic growth until 2013. The cumulative real GDP per capita growth during this period was $11.2 \%$. This upward trend was halted after the Euromaidan (2013-2014), Russia's annexation of the Crimea and the fight against pro-Russian separatists in eastern Ukraine, as mentioned in Chapter 1. In 2014-2015, the real GDP per capita of Ukraine decreased by nearly $10 \%$. In 2018 , the GDP per capita in Ukraine was on the level of tiny, former soviet states, such as Moldova, Georgia and Armenia (according to purchasing power parity), and was three times lower than in Poland.

The financial sector was affected by the crisis resulting from abovementioned events. The value of deposits in 2015 decreased by $2 / 3$ compared to the value of deposits of 2013. There was a devaluation of the UAH, the foreign debt exceeded $\$ 47.5$ billion, and the total debt was $\$ 75$ billion. This political crisis affected the real economy (an approximately 50\% decrease in investment, and an increase in unemployment by around 3\%). In 2018, the state budget spent the largest expenses on servicing the foreign debt. After the events of 2014, the Ukrainian economy was declining. Negotiations with the International Monetary Fund (IMF) required the implementation of difficult reforms in exchange for further loan tranches. One of the conditions of the IMF was the unfreezing (deregulation) of natural gas prices. In practice, this meant that a sharp increase is gas prices. This in turn resulted in an increase in inflation (Figure 3.2).

The aim of this chapter is to present and discuss the structural changes in the GDP of Poland and Ukraine as a consequence of the institutional changes referred to in Chapters 1 and 2. 


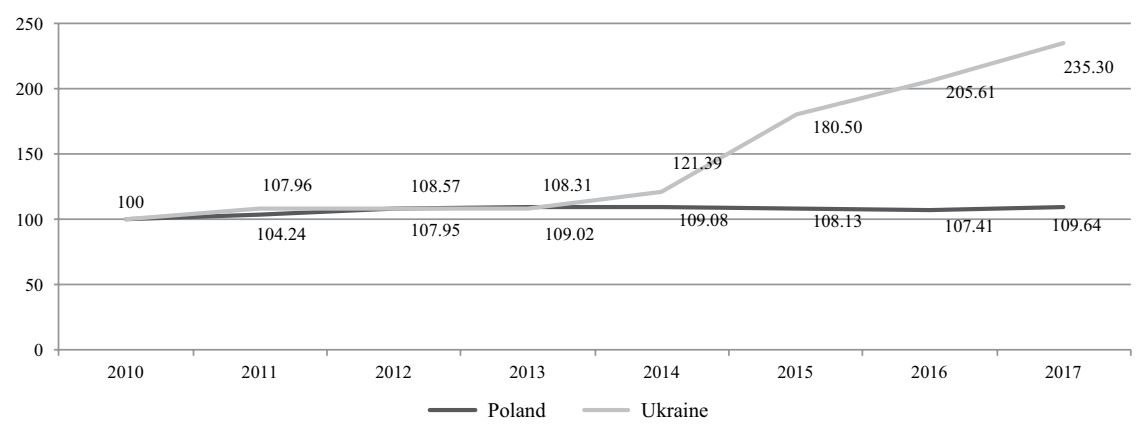

Figure 3.2 Consumer price index $(2010=100)$, Poland and Ukraine, 2010-2017.

Source: The World Bank Group, Indicators, (2019). (https://data.worldbank.org/indicator/ FP.CPI.TOTL?end=2017\&locations=PL-UA\&start=2010, access: $2019-12-30$ ).

\subsection{Share of the industrial sector in GDP}

The share of the industrial sector (mining, industrial processing, energy, construction) in the Ukrainian economy in the early 1990s was high; at the same time, however, it was characterized by significant volatility. In 1991, the share dropped to $55 \%$, in $1990-42 \%$, and between 1997and 1998, it fell to a level of approximately $30.5 \%$ of GDP.

The sharp decline in the GDP share of Ukrainian industrial sector between 1991 and 1998 was a consequence of:

- the slow process of ownership transformation (privatization) of stateowned industrial enterprises,

- difficulties in expanding into foreign markets and the decapitalization fixed assets.

The low competitiveness of industrial products in the conditions of this transition and of the world market which was increasingly open to Ukraine led to a radical reduction in this sector's share of the Ukrainian GDP (Figure 3.3).

During the period of 1998-2017, there was a constant decline in the competitiveness of the Ukrainian industrial sector reinforced by political turmoil and domestic demand variability, a weakening of international competitiveness, violations of the free competition rules (unlawful enrichment of a very narrow social group) and corruption.

Over this same period, the Polish industrial sector held a stable average annual GDP share of $29 \%$. At the end of 2017 the share of the industrial sector in the Polish economy was $29.5 \%$, while in the Ukrainian economy it was $23.3 \%$. 


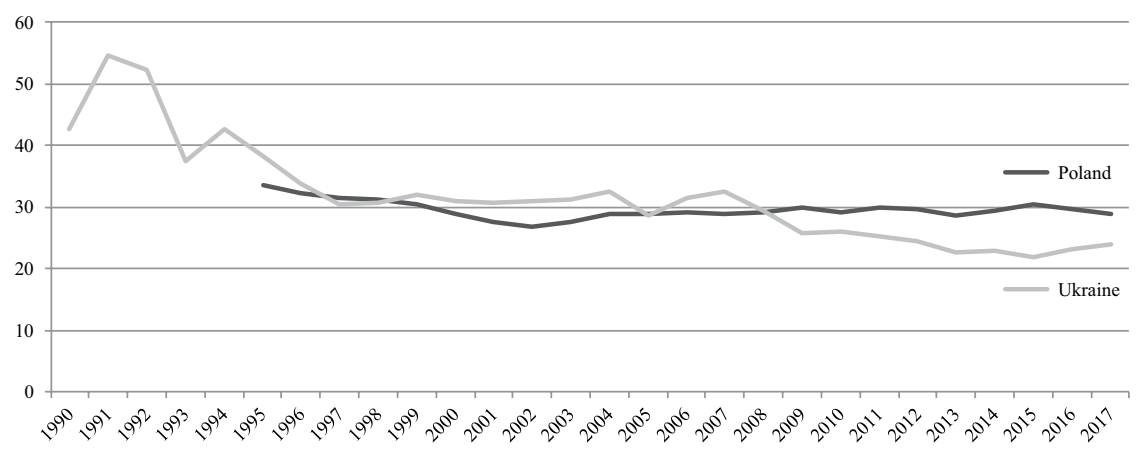

Figure 3.3 Changes in the gross value added of the industrial sector (ISIC: 10-45) in GDP (in \%), Poland and Ukraine.

Source: The World Bank Group, Indicators, (2019). (https://data.worldbank.org/indicator/ NV.IND.TOTL.ZS?locations=PL-UA\&view=chart, access: 2019-12-30).

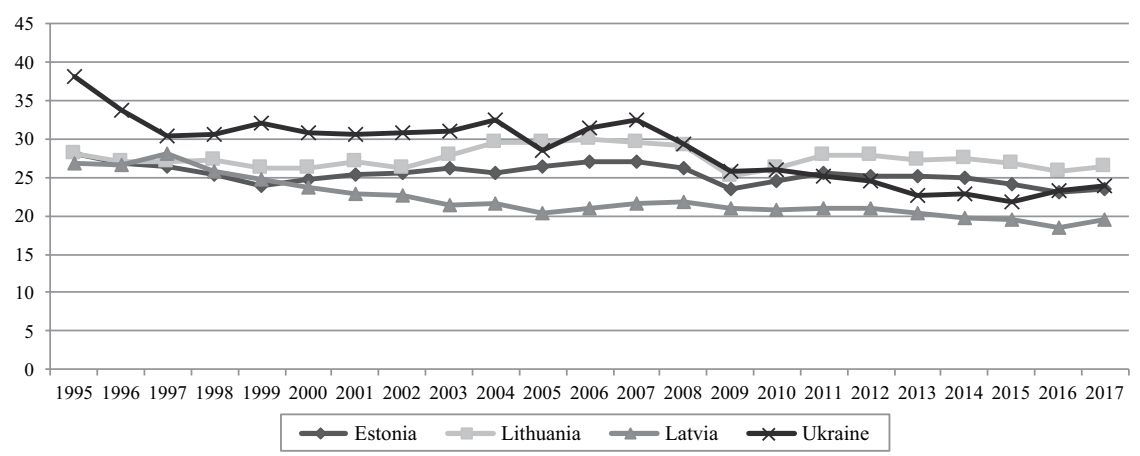

Figure 3.4 Changes in the gross value added of the industrial sector (ISIC: 10-45) in GDP (in \%), 1995-2017, The Baltic states and Ukraine.

Source: The World Bank Group, Indicators, (2019). (https://data.worldbank.org/indicator/ NV.IND.TOTL.ZS?locations=UA-EE-LT-LV\&view=chart, access: 2019-12-30).

In the emergent countries of the former USSR - which, like Poland, became members of the European Union, namely Lithuania, Latvia and Estonia - the GDP share of the industrial sector decreased steadily between 1995 and 2017. This process ran relatively calmly (Figure 3.4).

In the case of Lithuania, this share decreased by $1.8 \%$ points (pp), Estonia by $4.7 \mathrm{pp}$ and Latvia by $7.3 \mathrm{pp}$. Against this background, Ukraine stands out with an almost $14 \mathrm{pp}$ decrease over the last 23 years, as shown in Figure 3.5.

During the period considered, the Visegrád Group countries (Visegrád Four, V4) - Czechia, Hungary, Poland and Slovakia - were characterized by a stable GDP share of the industrial processing sector. In the case of 


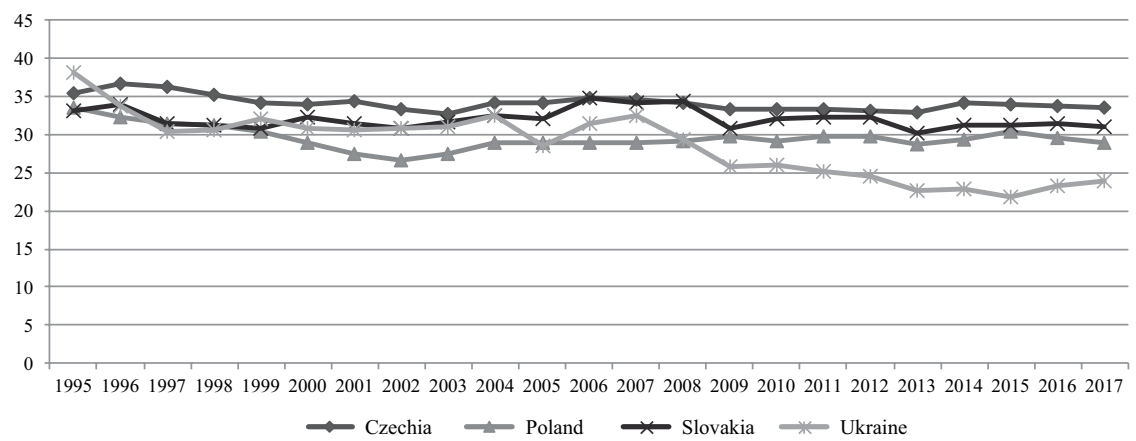

Figure 3.5 Changes in the gross value added of the industrial sector (ISIC: 10-45) in GDP (in \%), 1995-2017, The Visegrád group and Ukraine.

Source: The World Bank Group, Indicators, (2019). (https://data.worldbank.org/indicator/ NV.IND.TOTL.ZS?locations=UA-PL-HU-CZ-SK\&view=chart, access: 2019-12-30).

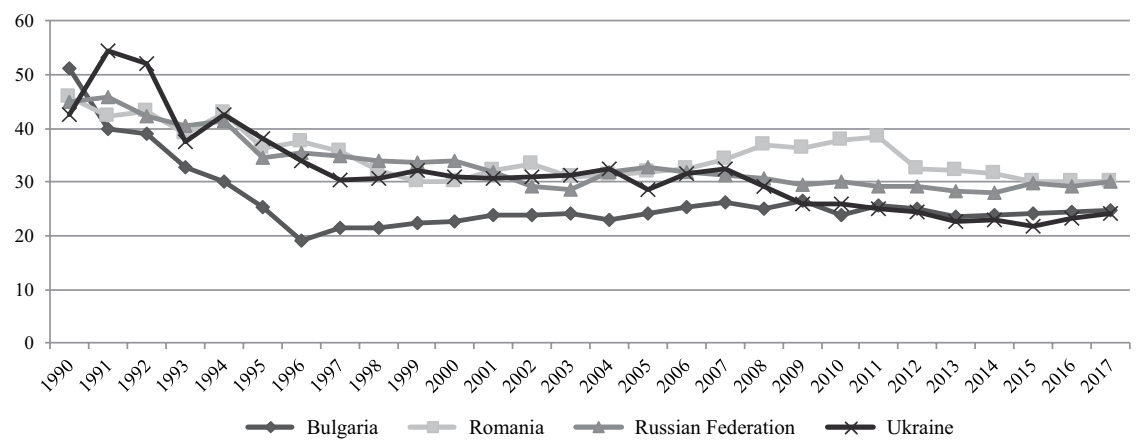

Figure 3.6 Changes in the gross value added of the industrial sector (ISIC: 10-45) in GDP (in \%), 1990-2017, Bulgaria, Romania, Russia and Ukraine.

Source: The World Bank Group, Indicators, (2019). (https://data.worldbank.org/indicator/ NV.IND.TOTL.ZS?locations=UA-RU-BG-RO\&view=chart, access: 2019-12-30).

Hungary, both in 1995 and 2017, this share remained at the same level of $26 \%$. Similarly, in Czechia, in 1995, this share was 35.3\%; however, over 23 years it decreased slightly to $33.5 \%$ - the largest GDP share in the group as a whole. Slovakia was the last country to start reform and has taken the longest in the V4 group. However, Slovakia has been dependent on the raw materials and the economy of Russia; therefore, this change was just above 1 pp over the entire 22-year period (Figure 3.6).

A common feature of Ukraine, Russia, Romania and Bulgaria was the sharp collapse in the economic activity of industrial companies in the first half of the 1990s. The hardest collapse was experienced by Bulgarian 
industry, down from a nearly $52 \%$ share of GDP (1990) to barely a $19 \%$ share in 1996. In 2017, industry produced a $24 \%$ stream of the global production of the Bulgarian economy.

The slow, systematic decline in the Russian industrial GDP share over the last 3 decades indicates evolutionary changes in the GDP structure, rather than a sharp collapse in its competitiveness. Romania has had the highest volatility regarding the industry GDP share of industry. At the beginning of the 1990s, as in the case of the other countries, this share was high, close to $46 \%$ of GDP. In 2000, it fell to its lowest level (30.1\%); however, it increased by $8.5 \%$ over the next 11 years. In 2017 , it returned to its 2000 level.

\subsection{GDP share of the agricultural sector}

The share of the agricultural sector in the Ukrainian economy in the early 1990 s was close to $25 \%$, while the industrial processing sector accounted for a total of $80 \%$ of the stream of GDP produced. Between 1995 and 2001 , the share of agriculture hovered between $14.5 \%$ and $12 \%$; in 2007 , it fell to its lowest level in Ukraine's history (6.6\%). The period 2008-2015 manifested a consistent marked increase in the share of agricultural production in GDP (an increase of 5.5\% points). In 2017, this share was $10.1 \%$ (Figure 3.7).

In the same period, production of the Polish agricultural sector reduced its share of GDP from $5.5 \%$ to $2.8 \%$. The importance of agricultural work

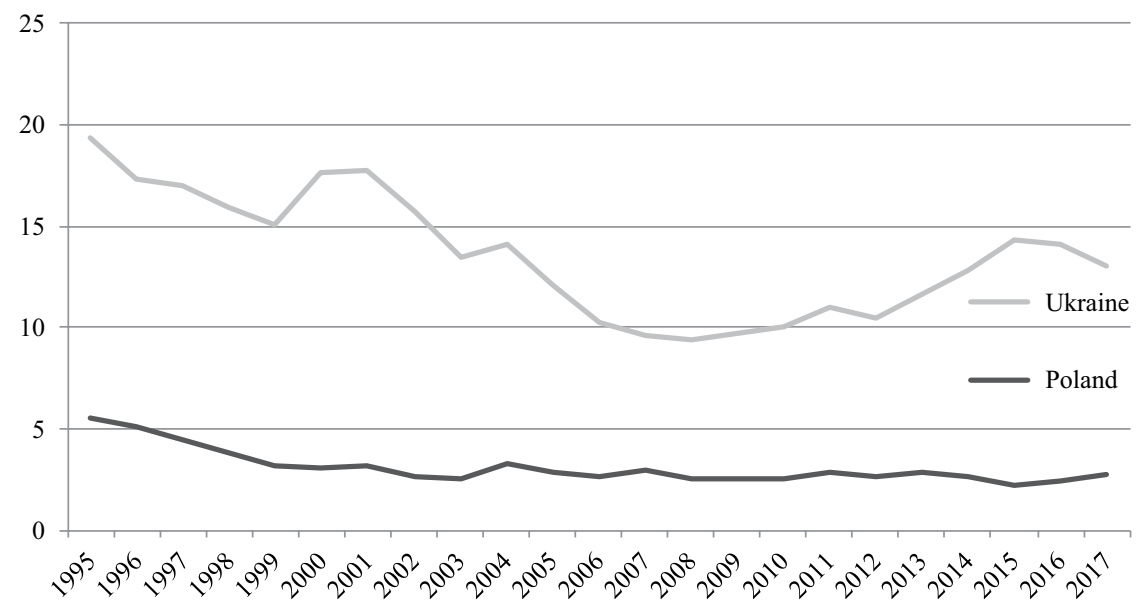

Figure 3.7 Changes in the gross value added of the agricultural sector (ISIC: $1-5$ ) in GDP (in \%), 1995-2017.

Source: The World Bank Group, Indicators, (2019). (https://data.worldbank.org/indicator/ NV.AGR.TOTL.ZS?locations=PL-UA\&view=chart, access: 2019-12-30). 
measured by the gross value per employee was one of the lowest compared to other EU Member States. It was a consequence:

- of the fragmentation of Polish agriculture,

- an unfavorable agriculture structure,

- the low economic strength of agricultural holdings, as well as

- a lack of modern machinery and equipment on the farms.

The proportion of workers employed exclusively in Polish agriculture has been steadily declining since the early 1990 s, when around 100,000 people worked in this sector of the economy, $27 \%$ of the total number of those employed. In 2004, about 100,000 people worked in agriculture, that is, $16.5 \%$ of the total number of employees, or 2.1 million people. In 2018 this number increased to 1.6 million people (i.e., $9.7 \%$ of the total workforce in the national economy) (Figures 3.8 and 3.9).

In the Baltic States, between 1995 and 2017, the share of the agricultural sector in GDP decreased steadily:

- $\quad$ in Lithuania from $10 \%$ (1995) to $3 \%$ (in 2017),

- in Latvia from $8 \%$ to $3.4 \%$, and

- in Estonia from $5 \%$ to $2.5 \%$.

Following the accession of the Baltic states (Lithuania, Latvia and Estonia) and the EU V4 countries, the share of agricultural production in GDP has remained stable at $3 \%( \pm 1 \%)$. The decline in the share of the agricultural sector in GDP over the last 23 years has been gradual and was the result of a more rapid growth in the remaining sectors. At the end of 2017, the share of the agricultural sector in GDP in Hungary and Slovakia was 3.3\%, in Poland it was 2.8\%, and in Czechia it was 2.2\% (Figure 3.10).

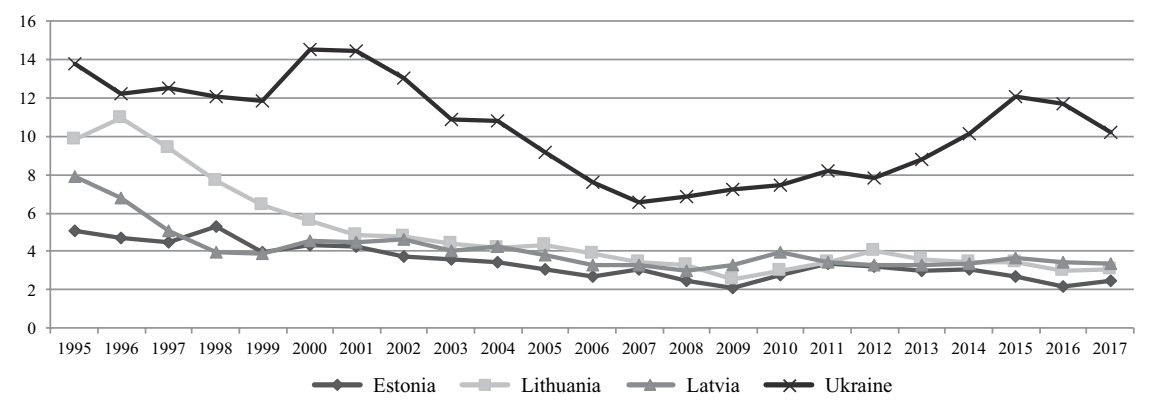

Figure 3.8 Changes in the gross value added of the agricultural sector (ISIC: $1-5$ ) in GDP (in \%), 1995-2017, the Baltic states.

Source: The World Bank Group, Indicators, (2019). (https://data.worldbank.org/indicator/ NV.AGR.TOTL.ZS?locations=UA-EE-LT-LV\&view=chart, access: 2019-12-30). 


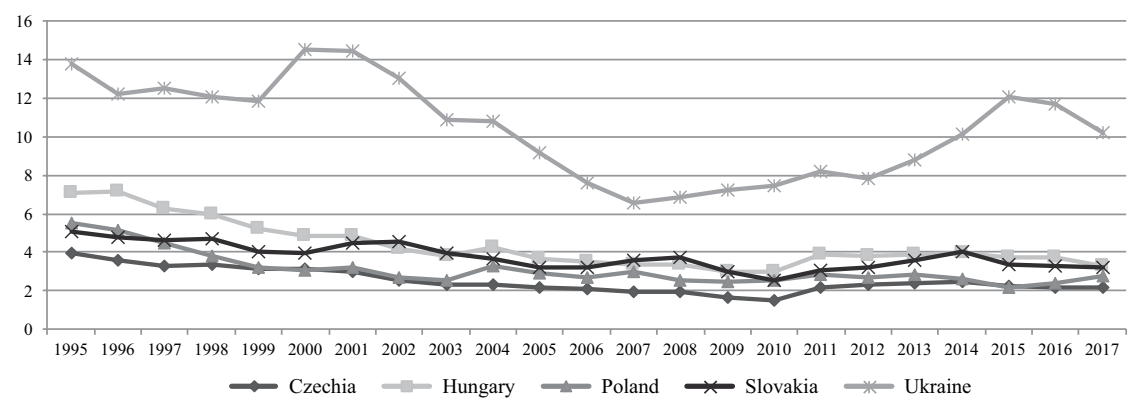

Figure 3.9 Changes in the gross value added of the agricultural sector (ISIC: $1-5$ ) in GDP (in \%), 1995-2017, the Visegrád Group.

Source: The World Bank Group, Indicators, (2019). (https://data.worldbank.org/indicator/ NV.AGR.TOTL.ZS?locations=UA-PL-HU-CZ-SK\&view=chart, access: 2019-12-30).

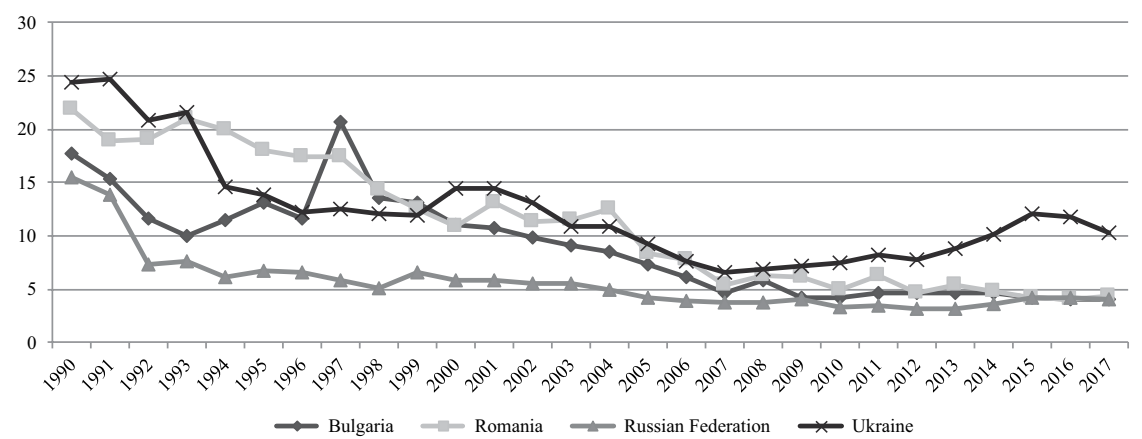

Figure 3.10 Changes in the gross value added of the agricultural sector (ISIC: $1-5$ ) in GDP (on \%), 1990-2017, Bulgaria, Romania, Russia and Ukraine.

Source: The World Bank Group, Indicators, (2019). (https://data.worldbank.org/indicator/ NV.AGR.TOTL.ZS?locations=UA-RU-BG-RO\&view=chart, access: 2019-12-30).

The common feature of Ukraine, Russia, Romania and Bulgaria was a much more significant decrease in the share of the gross value added of the agricultural sector in GDP compared to the other groups of countries analyzed. The share of the agricultural sector in the Ukrainian economy in the early 1990 s was close to $25 \%$ of GDP. In 2017 , this share decreased to $10.1 \%$ of GDP. In the case of Romania, there was a decrease from $22 \%$ of the share of GDP (in 1990) to 4.3\% (2017 and 2018). In Bulgaria, in 1990, the agricultural sector's share of GDP was $17.7 \%$ and decreased to $9.2 \%$ in 1995 , and in 1997, it increased to its highest level (20.6\%) during the period of economic transition. At the end of 2017, it was only $4 \%$.

The reduction in the gross value-added share of the agricultural sector in Russian GDP was relatively calm, outside the 1990 period $(15.4 \%$ 
share) - 1998 (5.1\%). Between 1999 and 2017, this share decreased by 3.4\% points, that is, to $3.1 \%$ of GDP.

\subsection{GDP selected components from the distribution side}

\subsubsection{Total investment expenditure}

The investment ${ }^{1}$ rate in Poland between 1995 and 2018 ranged from 17.5\% $(1995,2017)$ to $24 \%$ (1999-2000). The average investment rate in Poland for this period was $20.2 \%$ of GDP. This was significantly lower than Estonia's average of $28.1 \%$ and that of Latvia, $24.2 \%$. The average value of this parameter for the Lithuanian economy was $21 \%$, and for the Ukrainian economy $19.1 \%$.

The group's highest investment rates in 2007 were a common feature for all the countries analyzed. Over the next decade, the investment rates of these countries have not come close to the level of 2007.

- $\quad$ Estonia, Latvia approx. 36.5\% of GDP (2007), 2018 - Estonia 23.9\%, Latvia $22.8 \%$

- $\quad$ Lithuania $28.5 \%$ (2007), $19.3 \%$ in 2018

- Ukraine $26.1 \%$ (2007), $17.2 \%$ in 2018

- $\quad$ Poland 22.5\% (2007), 11 years later, $18.2 \%$.

The average investment rate for EU Member States in 2018 was around $20.5 \%$, while for the Euro zone it was $20.8 \%$.

The general regularities emerging from Figure 3.11 were (1) during the analyzed period (1995-2018), investment rates in Ukraine and Poland were almost lower in each year and often significantly lower than in Czechia, Slovakia and Hungary; (2) the average annual investment rate in Czechia was the highest in the group under consideration at 28.3\% of GDP, for Slovakia it was $26.1 \%$. Hungary's average investment rate $(22.8 \%)$ was also significantly higher than in Poland and Ukraine (Figure 3.12).

The average investment rates for the period of 1995-2018 for Ukraine (19.1\%), Russia (19.8\%), and Poland and Bulgaria (in both cases 20.2\%) are relatively close to each other. Romania $(24.1 \%)$ is characterized by a significantly higher average investment rate. Bulgaria (4.5\% in 1996; 33\% in 2008) and Romania (18\% in $1999 ; 37.2 \%$ in 2008 ) had the highest volatility of annual investment rates (Figure 3.13).

Investment rates in Poland and Ukraine are lower than in the other countries of Central and Eastern Europe. From the point of view of international competitiveness and the development prospects of both economies, this is a negative factor. Part of the difference between the investment rate in Poland and Ukraine, and the other countries of the region, is the sectorial structure of these economies. If the share of individual sectors in creating added value in Poland and Ukraine was at the average of EU countries in general, their 


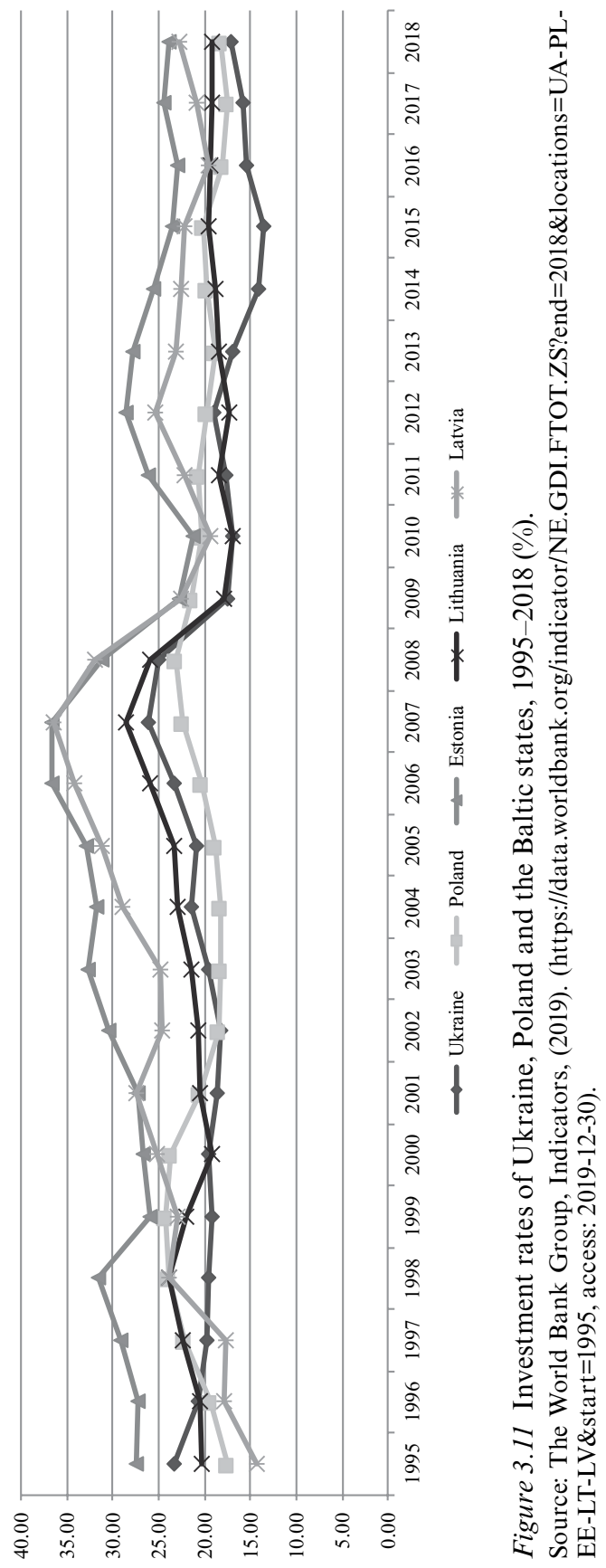




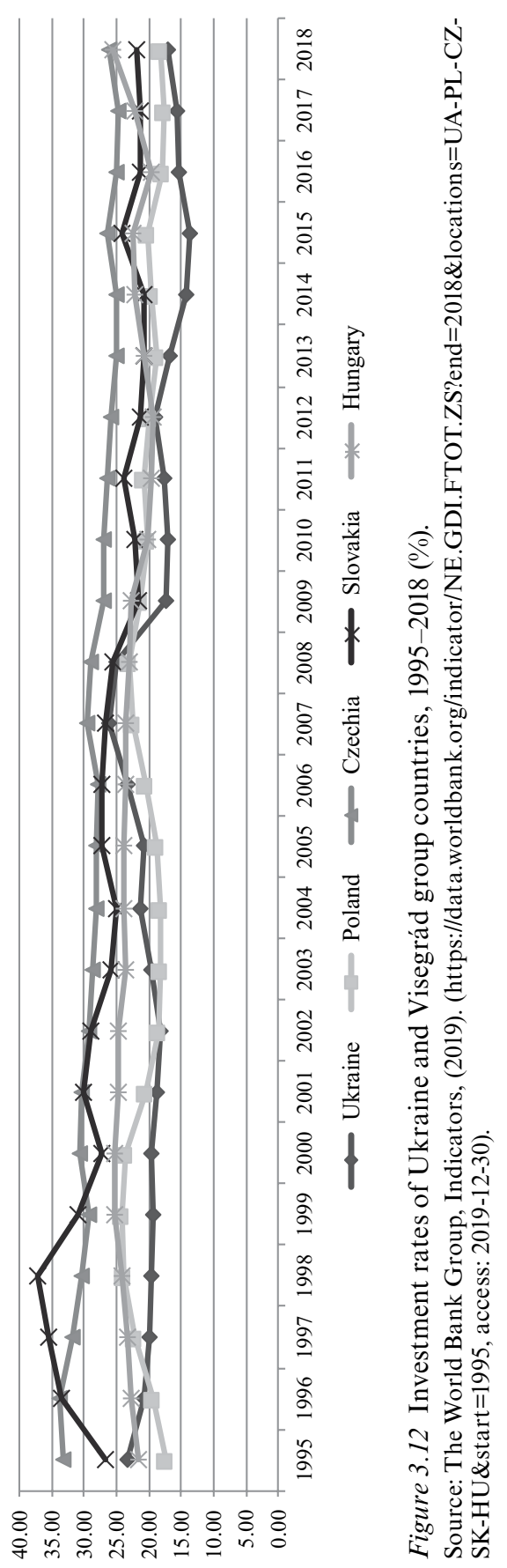


52 Rafat Wista et al.

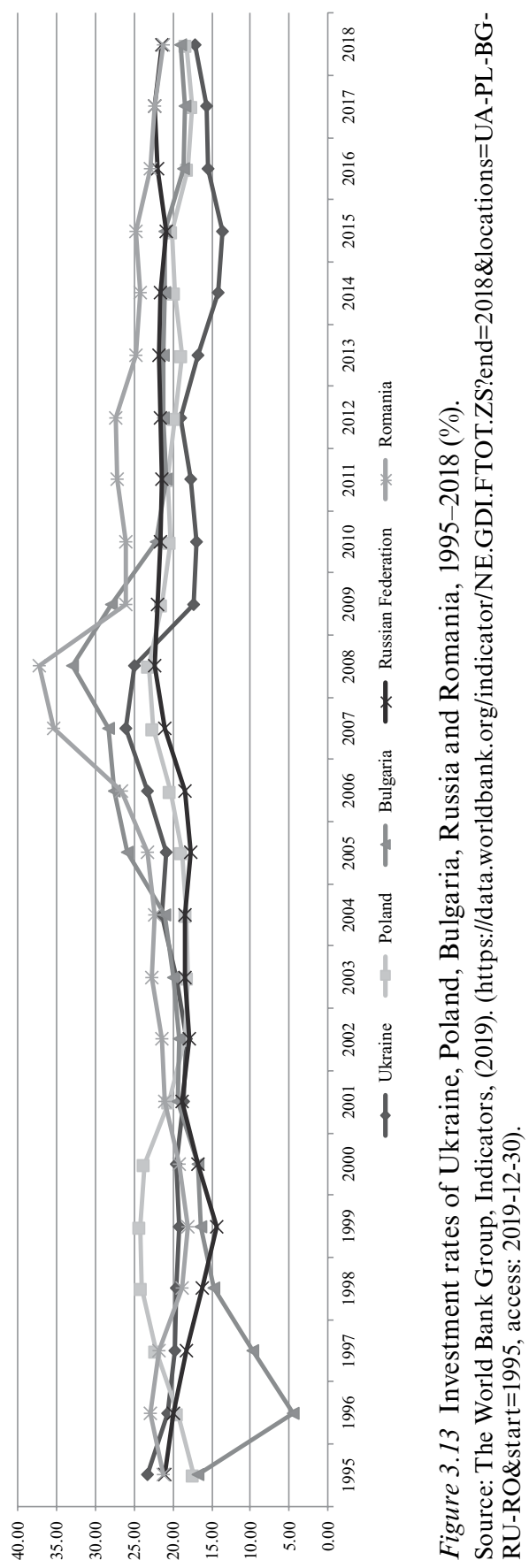


investment rates would probably be higher. The investment economic fluctuations in Poland between 1995 and 2018 are highly synchronized with the EU (0.54) and, in particular, with the Euro zone. The correlation of GDP is around 0.6. This relationship weakened significantly after 2008 (0.15), when the pro-cyclicality of investments in Poland decreased. On the other hand, the degree of synchronization of the economic cycle between Poland and the EU remained high.

What is surprising is the level of the correlation index (Pearson) for Ukraine and the EU. For the period of 1995-2018 it was 0.80, and for 20082018 it rose to 0.84. Between 1995 and 2007, this synchronization was 0.41 .

The correlation rate of the investment rate changes in Poland and Ukraine, for the period 1995-2018 was 0.29; in 2008-2018 it rose to 0.65. Between 1995 and 2007, this interdependence was negative $(-0.09)$.

\subsubsection{R\&D expenditure}

Research and development expenditure (R\&D) spending in Poland, as well as for software and databases, remains particularly low. This is a negative factor from the point of view of the development prospects of the Polish economy.

R\&D outlays relative to GDP have not increased significantly since Poland entered the EU. In 2004 it reached $0.55 \%$, and in 2017 it increased to $1 \%$ of GDP. In the EU, the average level is twice as high (2.1\%), and the average value of this share for the Visegrád Four, without Poland, is about $1.4 \%$. Recognizing that R\&D capital expenditure promotes an increase in the total productivity of input and consequently economic growth, measures are systematically taken to support the activity and innovation of enterprises, including those of R\&D centers of global corporations. Such a process, although relatively slow, has been observed in Poland (Figure 3.14).

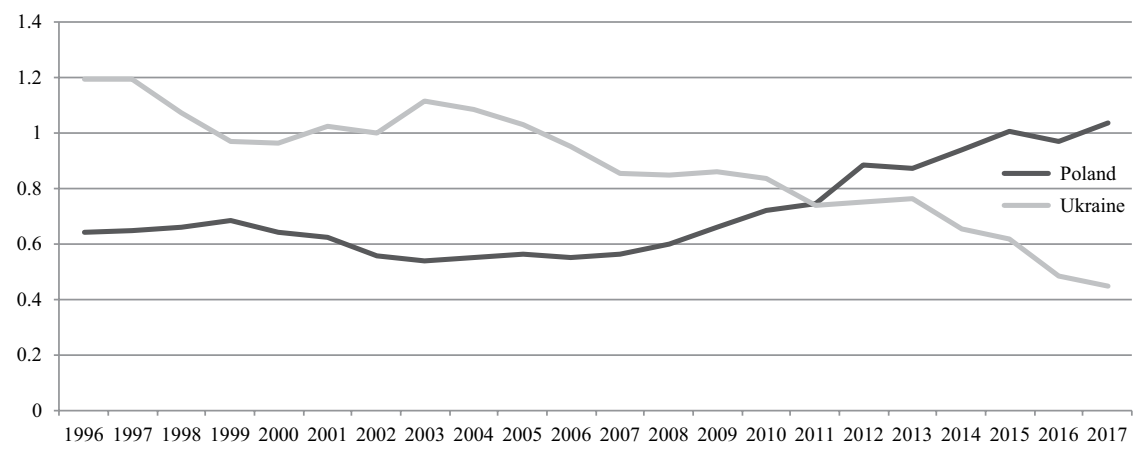

Figure 3.14 Changes in the share of R\&D expenditures in GDP (in \%), 1996-2017, Poland and Ukraine.

Source: The World Bank Group, Indicators, (2019). (https://data.worldbank.org/indicator/ GB.XPD.RSDV.GD.ZS?locations=UA-PL\&view=chart, access: 2019-12-30). 
In the case of Ukraine, the R\&D investment expenditure level is consistently becoming less and less important; more than $1 \%$ in 2004 , it was down to just $0.4 \%$ in 2017 . Based on such a trend, it is possible to infer the fading potential for the development of the Ukrainian economy, with a source of technological progress and growth in productivity.

From the point of view of economic development prospects, both the investment rate and its structure are important. Against this background, in highly developed countries in recent decades, there is a noteworthy trend of systematic growth in the role of investment in intellectual property products, that is, research and development, computer software and databases. R\&D and software outlays display significantly higher growth rates than overall investment. The increase in investment rates in intellectual property products, from a theoretical point of view, is linked to an increase in the innovative potential of the economy.

\subsubsection{National defense spending}

Poland has spent $2 \%$ of GDP on defense per annum, on average, over the last 25 years. With an average annual 4\% economic growth during this period, this means, in practice, a systematic increase in real defense spending for Poland. In most geopolitically stable countries in the world, defense spending is approximately $1 \%$ of GDP (Figure 3.15).

In 1993, the share of defense spending in Ukraine's GDP was $0.44 \%$, while the real value was $\$ 642.4$ million (in fixed 2010 prices). In 1997, this share increased to $4 \%$, which in fact meant an expenditure of $\$ 3.44$ billion (in fixed 2010 prices). Between 1993 and 1997, Ukraine's GDP decreased from $\$ 146$ billion to $\$ 86$ billion. Between 1997 and 2013, military spending decreased to a level of $2.4 \%$ of GDP, with a real value at the 1997 level.

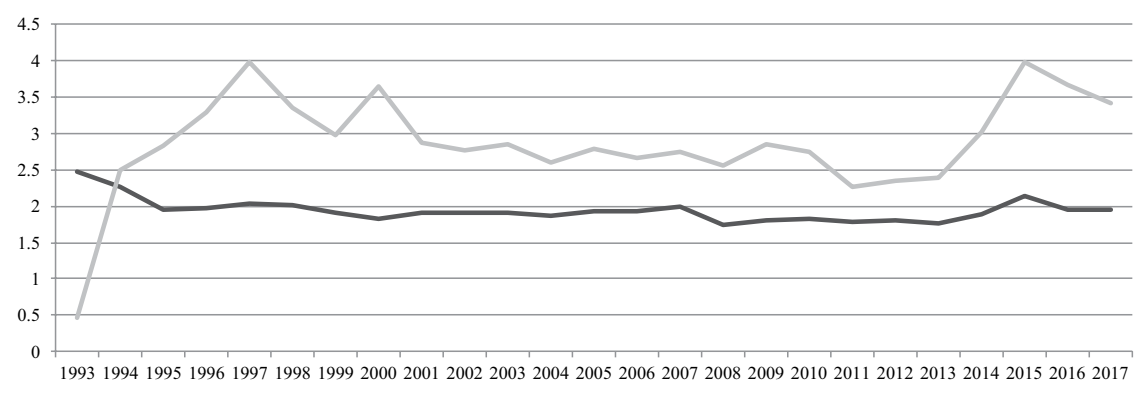

Figure 3.15 Changes in the share of defense spending in GDP (in \%), 1993-2017, Poland and Ukraine.

Source: The World Bank Group, Indicators, (2019). (https://data.worldbank.org/indicator/ MS.MIL.XPND.GD.ZS?end=2017\&locations $=$ UA-PL\&start $=1993 \&$ view $=$ chart, access: 2019-12-30). 
The political tensions that Ukraine has been embroiled in since 2013 pushed defense spending up again to $4 \%$ of GDP in 2015 , that is, to $\$ 4.84$ billion in real terms (in fixed 2010 prices). In 2017, this value fell to $\$ 4.1$ billion, or $3.24 \%$ of GDP. Social and political instability after the Euromaidan of 2013-2014, Russia's annexation of Crimea and the fight against pro-Russian separatists in eastern Ukraine have resulted in a marked increase in this category of public spending in 2014-2015 (by about \$1.4 billion).

\subsection{Summary}

Poland, after the period of a centrally planned economy (1946-1989), in the early 1990s, had at its disposal several basic or well-trained institutions typical of a market economy.

At the beginning of the 1990s, Ukraine did not have any institutions with experience in building a market economy, or the institutions of parliamentary democracy. Ukrainian society had to face the extremely difficult task of creating market economy institutions from scratch. In Poland, the GDP per capita has increased by $190 \%$ over the last almost 30 years from 9,500 dollars (1991) to 27,300 dollars (2017). When we consider 2018, the Polish GDP per capita is three times the value of 1991.

The Ukrainian GDP per capita in 2017 has still not returned to its 1991 level. GDP per capita in Ukraine is currently at the level of Moldova, Georgia and Armenia and is three times lower than in Poland. The main brake on Ukraine's GDP growth is established informal non-market institutions, which are not conducive to free competition (clan interest networks and corruption).

Between 1991 and 2017, the low competitiveness of industrial products combined with the lack of managerial competence to operate under a growing market economy resulted in a radical reduction in the share of the processing sector in the Ukrainian GDP. This trend was reinforced by political turmoil and the volatility of domestic demand. Between 1991 and 2017, the Polish industrial sector held a stable $29 \%$ of average annual GDP. At the end of 2017, the share of the industrial sector in the Polish economy was $29.5 \%$, while in the Ukrainian economy, it was $23.3 \%$.

The share of the agricultural sector in the Ukrainian economy in the early 1990 s was close to $25 \%$. In 2017, this share was $10.1 \%$. During the same period, the agricultural sector's share of Polish GDP was reduced from 5.5\% to $2.8 \%$. The productivity of agricultural labor, measured by the gross value per employee, was one of the lowest, when compared to other EU Member States.

Economic fluctuations in investment in Poland (1995-2018) are highly synchronized with the average investment rate of EU Member States (0.54); by comparison, the similarly calculated GDP correlation is around 0.6. For Ukraine and all EU Member States, this interdependence is at an even 


\section{Rafat Wista et al.}

higher level (0.84). R\&D spending relative to GDP has increased since Poland's entry into the EU. In 2004, it was $0.55 \%$ and increased to $1 \%$ of GDP in 2017. In the case of Ukraine, a contrary trend is observed - from more than a $1 \%$ share in $2004, \mathrm{R} \& \mathrm{D}$ spending fell to just $0.45 \%$ in 2017 .

\section{Note}

1 Gross expenditure per fixed assets to GDP. 